\title{
Post-Soviet States Between Russia and the EU: Reviving Geopolitical Competition? A Dual Perspective
}

\author{
Teodor Lucian Moga and Denis Alexeev*
}

The last two decades have witnessed a tectonic upheaval in the international political milieu. In Eastern Europe, the collapse of the Soviet Union meant the sudden emergence of newly independent states and required a quick and proper reaction to the changing geopolitical context. Such is the challenge confronting Russia and the European Union (EU), the two major players in the region. In times of economic crisis and political uncertainty, both parties seek to achieve their goals and protect their interests in the shared vicinity by expanding cooperation with their neighbors. However, each side is conducting its actions in a different fashion, according to its own strategic plans. The pressing issue coming out of this situation is whether it is possible to label this dual struggle for broader political clout a new strategic competition. Or it is just an inevitable process of restructuring the regional political environment - a process that is still incomplete after the dissolution of the Soviet Union? Thus, this essay examines the practical nature and the ideological background of both the EU and Russian approaches and policies towards the common proximity of the former Soviet republics.

$* * *$

The growing importance of the EU as a strong center of gravity in the European postCold War milieu, coupled with the collapse of the Soviet Union, has sparked the development of a wide range of cooperative mechanisms between the Union and its Eastern European neighbors. The EU's increasing geopolitical weight has taken concrete form through the development of its enlargement strategy and the launch of the Common Foreign and Security Policy (CFSP), followed by the Common Security and Defense Policy (CSDP). The European Neighbourhood Policy (ENP) and, most recently, the Eastern Partnership (EaP) have been envisaged in the case of Eastern Europe as alternatives to the enlargement strategy, albeit this equivalency has not been officially stated. They were policies meant to enhance political dialogue and cooperation in many areas, ranging from security issues to trade, migration, visa facilitation, energy, and environment. A number of relevant projects have been set up, such as the Deep and Comprehensive Free Trade Agreements (part of the Association Agreements), institutional appropriation, common negotiation and cooperation platforms (cross-border links, Euro-regions, civil society and business forums, biennial summits, annual ministerial meetings, etc.). This article holds that the Union's paramount goals in Eastern Europe have been first and

Teodor Lucian Moga is lecturer at the Alexandru Ioan Cuza University of Iasi and former researcher at the Romanian Academy of Science. Denis Alexeev is Associate Professor of International Relations at Saratov University, Russia and Visiting Fellow at George C. Marshall European Center for Security Studies, Germany. The views expressed here are solely those of the authors. 
foremost regional stability and security. However, Brussels has realized that the EU could best promote stability and security indirectly through measures aimed at encouraging the spread of democracy, human rights, good governance, and market economy. Moreover, in order to attain the aforementioned objectives, the EU should further engage in the wider European security environment (through its CFSP/CSDP instruments) and seek to strike a balanced stance towards Russia. Amid sensitive issues, EU policy makers and heads of state need also to work to arrive at a consensus with Moscow that might involve common approaches for facilitating regional cooperation.

The strategy centered on the integration-security spectrum has been the main rationale that stood behind the EU's approach towards Eastern Europe. The ideas under which the European integration process has been conceived dealt with threats and risks in a rather politicized way, rather than using hard power (best reflected in the concentric circles model). This is because Brussels perceives regional stability from a liberal security perspective of normative transformation based on the EU's core values: democratization, rule of law, human rights, and market economy. This perception stands in contrast to the more traditional realist understandings of international relations, premised on material interests and balance of power. However, in the Eastern neighborhood of the EU, this article argues that an interplay of liberal/realist perceptions of security exists, and that it stems from the persistence of a geostrategic competition between the EU and Russia over the post-Soviet Newly Independent States (NIS). Because of their sensitive "pivot" location, the NIS are often regarded as a bone of contention between the two regional players.

The EU enlargement process to include countries in Central and Eastern Europe has shed light on new territorial horizons by bringing parts of the former Soviet space into the EU's focus. But since the enlargement solution to pan-European security has reached an obvious point of fatigue (nearly to exhaustion), ${ }^{1}$ Brussels has devoted its support to developing alternative cooperative arrangements, such as the development of the ENP, aimed at forging a new way of approaching the immediate neighborhood. This has meant the creation of a stable area, a ring of friends at the EU's borders, which in turn would ensure regional security. ${ }^{2}$ According to the aforementioned concentric circles model, the first ring (circle) is represented by the EU itself, governed by a series of laws,

Despite Croatia's accession to the EU on 1 July 2013.

2 It should be noted from the outset that the ENP was adjacent to, but distinct from the EU's enlargement policy. This policy cannot be regarded as a pre-accession exercise, as the states concerned have not been targeted as potential EU candidates. Belonging to Europe and being associated with Europe are two distinct phases that draw a blurred line between the EU states and their neighbors. "The blurring of a boundary, however, does not then mean its elimination but that interactions across the line take on an increased intensity and complexity. This amounts, in short, to a growing interdependence between the EU and its neighbours, and requires deliberate efforts by both sides to manage effectively that interdependence.” Michael Smith and Mark Weber, "Political Dialogue and Security in the European Neighbourhood: The Virtues and Limits of 'New Partnership Perspectives'," European Foreign Affairs Review 13 (2008): 74. 
norms, and rules known as acquis communautaire. The second circle consists in the European Economic Area (EEA), created in 1994 between the members of the EU and the three states of the European Free Trade Association (Norway, Iceland, and Lichtenstein) by the adoption of the internal market acquis. The third circle contains the states subject to the enlargement process: the states in the former Yugoslav space, Turkey, and Iceland. This meant a gradual and significant yet far from complete adoption of the $a c-$ quis. The ENP represents the fourth and the largest circle gravitating around the EU, comprising six former Soviet states from Eastern Europe and also the ten Mediterranean states included in the Barcelona Process. These states exhibit flaws in political and economic governance, and the EU acquis is being only selectively introduced, according to the will and capacity of absorption of each state. Some countries from the eastern rim of Europe (Moldova, Ukraine, and Georgia) aspire to a long-term perspective of accession into the European structures, but this is not currently encouraged; Brussels provides them instead the possibility of economic integration and thorough Association Agreements. ${ }^{3}$ Moreover, in Eastern Europe, the ENP's additional multilateral frameworksthe Eastern Partnership (EaP) and Black Sea Synergy (BSS)—reiterate Brussels' interest in the eastern proximity of the EU by providing the premises for pushing the states involved a step closer to the EU.

Security has again been a salient issue. The timing of the policies illustrate, among other things, that they were designed in response to new security challenges. The ENP emerged in the aftermath of the big 2004 enlargement, and shortly before Romania and Bulgaria became members (2007), which brought a troubled region closer to the EU's borders. The EaP (2009) came about as a result of Russia's August 2008 invasion of Georgia (most prominently), the gas disputes between Gazprom and Kiev (2006, 2009), the growing interest in energy supplies, and the persistence of the protracted conflicts in Transnistria, South Ossetia, Abkhazia, and Nagorno-Karabakh. Complementarily, the Black Sea Synergy (2007) has been envisaged as helping to avoid any other geopolitical divisions around the Black Sea basin and to further regional cooperation between the region's littoral states (Bulgaria, Georgia, Romania, Russia, Turkey, and Ukraine) and adjacent states (Armenia, Azerbaijan, Greece, and Moldova). This increased concern for security beyond the borders of the EU followed the same rationale that underpinned the enlargement strategy following the dissolution of Yugoslavia (1991-95) and the war in Kosovo in 1999. The devastating events of the 1990s gave momentum to a consideration of enlargement both as a response to the threats of authoritarian revival and ethnic conflict and as a strategy for security promotion in Central and South Eastern Europe, first by including the Visegrad countries and then Romania and Bulgaria.

A brief analysis of the eastern neighborhood "grand chessboard" of the EU cannot ignore the region's geopolitical complexity. In Eastern Europe, the Euro-Atlantic community, on the one hand, and Russia on the other seek to assert their influence and de-

3 It was expected that talks on the Association Agreements (AAs) would be finalized around the time of the EU-Eastern Partnership summit in Vilnius on 28-29 November 2013, which will eventually reshape their relationship with the Union. 
lineate their spheres of interest. These spheres often overlap, leading to consequences at the local and national level. Such is the case of the six EaP states (Moldova, Ukraine, Belarus, Georgia, Armenia, and Azerbaijan), whose geographic position of "in-betweenness" constrains their internal and external political decisions. Since their emergence as independent states after the disintegration of the USSR, these states have walked an unstable political tightrope, a multifaceted judgment often being employed to strike a balance between East and West. To a certain extent, this multi-vectoralismfomented also by Brussels' deliberate ambiguity—weakens the neighborhood policy's credentials as being a reliable tool to fulfill its agenda. ${ }^{4}$ Moreover, the current economic downturn has frequently hindered or postponed Brussels' plans towards its vicinity.

In Eastern Europe, the EU and Russia are the most important actors in the shared vicinity, both exercising structural and normative power to shape their neighboring environment and both trying to coordinate the external challenges emanating from the region. Moscow is generally considered as a normative and political rival to Brussels, and consequently as the main stumbling block to any cooperation between the EU and the EaP states. Since the launch of the ENP and, particularly, the EaP and the BSS, Russia has opposed any institutional encroachment upon its own neighborhood, and has thus adopted an antagonistic stance toward the ENP (first by assuming an alarmist approach towards the EaP, which was regarded as premeditated intrusion into Moscow's region of "privileged interest," 5 and later by downplaying the EU's neighborhood initiatives and by launching competing agendas). Russia spearheaded the creation of the Customs Union (2010) and the Common Economic Space (2012) between Russia, Belarus, and Kazakhstan, and Vladimir Putin's project of a Eurasian Union (2015) is at odds with the EU's goals. By and large, Russia rejects the implication carried by the ENP that European values, norms, and practices are the only game in town.

Over the last two decades the EU has been an anchor of stability for neighboring countries, and has influenced to a considerable extent their economic and political institution-building process. Economic cooperation has triggered further integration and consolidated interdependence and, not coincidentally, a feeling of reliance (of trust) between states. This rationale has not changed in the last couple of years; however, the EU's economic strength is fading. As the single market, the monetary union, and the constitutional treaty have been seriously shaken, this has cast doubt on the EU's internal and external governance models. Moreover, in spite of growing dialogue, and several initiatives and institutional collaborations, reform on the ground has been limited, while political freedom and civil liberties are still a sensitive issue in the western post-Soviet states (Moldova, Ukraine, and Belarus) and the South Caucasus (Georgia, Armenia, and Azerbaijan). The rise of the authoritarian and "hybrid" regimes in these states (defined

4 The EU members are often divided over the appropriate approach vis-à-vis the six post-Soviet states. Whereas Poland, the Baltic states, Sweden, Slovakia, and Romania are the most vocal advocates of deepening relations between Brussels and the EaP states, the other EU members are rather cautious, if not reluctant.

5 Oana Lungescu, “EU Reaches out Toward Troubled East,” BBC News, 7 May 2009; available at http://news.bbc.co.uk/2/hi/europe/8035710.stm. 
as neither completely authoritarian nor completely democratic) has been highlighted in all international ratings. And this is surprising for countries located on the EU's eastern fringe, where Union influence is supposed to be strong. Furthermore, the EU's reluctance to meet the membership aspirations of some of the EaP countries will continue to hinder the development of further relations.

The EU has the capacity and necessary means to play a vital role in Eastern Europe. From this standpoint, expressions such as "enlargement fatigue," "third countries," "partial inclusion," "anything but institutions," etc.-phrases that are often used in the EaP progress reports-seem counterproductive and create ambiguity. The principle of "more for more" that the EU is using with respect to its neighborhood should also be applied to Brussels' agenda. Lately the EU has emerged as being willing to offer less in relation to the post-Soviet space, which could look hazardous for the near future and detach the EaP from the EU's orbit. Hence, a much more vigorous political determination and stronger common voice could increase the EU's weight and influence and bring added value to its external governance. The EU should practice and invest more in what it preaches and stands for. And this could involve the need for an ambitious overhaul of Brussels' toolkit in order to efficiently engage with countries for which the prospect of full-fledged membership is still not part of this relationship. While the EU is seriously rethinking its current role on the international stage where new global actors have risen, it should not forget that its main strategic power lies in its near abroad. Even the EU Commissioner for Enlargement and European Neighbourhood Policy Štefan Füle has stressed the importance of the Association Agreements as "a quantum leap towards the real transformation in that post soviet space" and "a game changer." stated in the European Commission's Strategy Paper, "Eastern Partnership: A Roadmap to the Autumn 2013 Summit”: "Cooperation between the EU and its Eastern European partners - the Republic of Armenia, the Republic of Azerbaijan, the Republic of Belarus, Georgia, the Republic of Moldova and Ukraine-is a crucial part of the Union's external relations." ${ }^{, 7}$ Thus, it becomes obvious that creating an integrative frame for regional cooperation depends, to the largest extent, upon the success of the external governance that the EU wishes to transfer to its vicinity.

Just like for the EU, the republics of the former Soviet Union occupy a very important place in Russia's foreign policy agenda. The long history of being a part of one state, as well as the wide spectrum of close economic, social, political, and cultural ties are inter-

6 Štefan Füle, “Ambitions of EU and East Partners for the Vilnius Summit,” Press Releases Rapid (28 May 2013); available at http://europa.eu/rapid/press-release_SPEECH-13477_en.htm.

7 European Commission, “Eastern Partnership: A Roadmap to the Autumn 2013 Summit,” May 2012, 1; available at http://ec.europa.eu/world/enp/docs/2012_enp_pack/e_pship_roadmap_ en.pdf. 
preted by Russia as a very strong argument in favor of searching for common strategies of cooperation and development in the twenty-first century.

The history of Russian efforts to reunify the post-Soviet space-with an accent on Russia's central role within new political, economic, and military constructions-dates back to the late 1990s. At that time, the Russian political establishment openly proclaimed the change in its foreign policy priorities from rapprochement with the West towards the deepening of relations and cooperation with the former Soviet republics. ${ }^{8}$ Russia's interest in strengthening its position in the post-Soviet space was not spontaneous. The series of economic and political crises that collapsed on Russia and its neighbors in the early 1990s resulted not only in economic weakness and political turbulence, but also in a constant U.S. and European presence in the NIS. This took shape in some bilateral and multilateral economic and energy projects, political and military assistance, and finally rounds of NATO and EU enlargement as strong evidence of expanding Western influence in the region. These steps were perceived by Russia as evidence of trends that that might lead to its isolation, undermining traditional concepts of national security. In other words, the major drivers for this new approach towards the neighborhood could be described as general disappointment in the rapprochement with the West, which neither brought expected levels of prosperity nor smooth integration of Russia into the Western community of nations. It was also perceived as a gradual loss of common ground and influence among the former Soviet republics, and finally, as an ideological shift among a new political elite (the idea of Russia's revival as a strong regional leader, supported by quick economic growth, oil prices, and favorable economic conditions).

The process of rethinking Russia's stance toward its neighbor states and the reunification strategy and ideology could be divided into three stages. The first stage extended from the late 1990s until the early 2000s, and was characterized by a reverse in Russian policy towards the Commonwealth of Independent States (CIS) after the rule of Boris Yeltsin. This period also saw the acceleration of cooperation with Russia's neighbors, and the implementation of some initiatives for the creation of a formal organizational network in the former USSR (e.g., the Eurasian Economic Community, Unification of Russia and Belarus, etc.) These organizations, despite their ambitious goals, were destined to remain nominal or demonstrate insignificant progress in their development due to a variety of internal economic and political problems Russia and many of its neighbors faced during this period. In general, Vladimir Putin's first presidential term was characterized by the elaboration of political and strategic mechanisms of strengthening influence over the post-Soviet space to sustain closer political and economic ties between Russia and the former Soviet republics.

8 This significant change of priorities toward CIS countries in Russian foreign policy was first articulated by then Minister of Foreign Affairs Evgeny Primakov in 1996-98. Later on, this idea was supported and developed by Vladimir Putin, who once called the collapse of Soviet Union "the greatest geopolitical catastrophe of twentieth century." 
The second stage occupied most of the mid-2000s, and was very much shaped by Russia's reaction to the series of "Color Revolutions" in Georgia, Ukraine, and the Kyrgyz Republic. As a result, this stage saw Russia's decisive turn towards its neighbors, and the display of a will to play a greater political role in the region, as well as strict competition with the United States and the European Union for economic and political influence in the former Soviet Republics. This is the stage when Russia started to exert pressure on its neighbors who openly demonstrated their ambitions for EU and NATO membership while simultaneously hoping to continue to enjoy economic benefits and energy subsides inherited from the Soviet past. ${ }^{9}$ These years proved to the Kremlin leadership that such a period of competition would require some strict measures to remain a strong player in the region, and, at the same time, the need for a long-term strategy that would enable Russia to envision a new paradigm for post-Soviet integration.

The third stage occupied the late 2000s, and was characterized by the systematization of Russia's political and economic approach. Elaboration of a long-term strategy based on the strengthening of the economic, military, and political ties with the post-Soviet states, which constitute the post-soviet integration core (Belarus and Kazakhstan), has demonstrated Russia's most prominent interest in regional integration since the Soviet Union's collapse. The third stage refers to a new integration logic, partly borrowed from the EU experience (where all of the existing political constructions are based on sustainable economic cooperation between major European players). This phase saw the development of a new cooperation and integration philosophy that was intended to boost rapprochement using more pragmatic mechanisms of mutual interest, especially in opening new markets and business opportunities. During the time of global economic turbulence, these measures could be perceived as a policy of pragmatic regionalism with certain ambitions for political integration.

Rethinking Russian policy toward its neighbor states can also be seen through the prism of two major tendencies: political and ideological. The first tendency appeared during the 1990s, and draws some of its internal factors from the period when the collapse of Soviet ideology, Russian economic decline, and general ideas of sovereignty and disintegration resulted in the destruction of the political and economic ties between former integral parts of the Soviet Union, combined with Russia's inability to remain a pole of gravity to former Soviet republics. The second tendency has had a pronounced external dimension, most notably during the 1990s and early 2000s when the intense actions of influential regional players like the U.S. and the EU were perceived in Russia as an attempt to exclude her from her traditional area of strategic interests. There was a solid basis for these kind of Russian concerns. The emergence of Western-oriented political and security alliances (GUUAM/GUAM), the support offered to some Russian neighbor states in fulfilling their NATO ambitions, and bilateral economic projects (which very often undermined Russian interests and created new barriers) provoked sus-

9 The mid-2000s resulted in the series of gas conflicts between Russia and Ukraine, a variety of Russian economic sanctions against some sensitive export products from Georgia and Moldova, arguments with Azerbaijan on the Baku-Tbilisi-Ceyhan pipeline, etc. 
picion vis-à-vis almost any type of European or U.S. blueprint toward the former Soviet states. Another external factor that raised serious concerns in Russia was the escalating competition between the U.S., EU, China, and Russia for access to energy resources and transportation routes in Central Asia and the Caucasus. A number of energy projects and the building of pipelines that provide alternative energy supplies to Europe seriously shook Russia's status of regional energy superpower (which became of paramount importance once global market prices for oil and gas started to rise significantly). It also forced Russia to adopt decisive economic and political measures against some neighbor states and to accelerate its actions to secure its status as the major energy source for Europe.

Finally, the process of regime change and the series of "Color Revolutions" "orchestrated by the West” not only nourished Russia’ s mistrust toward any European or U.S. initiative in the former Soviet space, but also produced a serious concern that such policies could be used at some point against Russia itself. ${ }^{10}$ This determined Russia to alter its foreign policy priorities and elaborate long-term strategies for dealing with its neighbors. One of the first conceptual theses undergirding Moscow's new strategy could be traced to "The New Eurasian Strategy," written by Sergey Rogov, the Director of the Institute of the U.S. and Canada at the Russian Academy of Sciences. His message was somehow a quintessence of ideas held by a large group of Russian politicians and intellectuals who were interested in reversing Russia's waning trend as a regional power. ${ }^{11}$ Even now, more than a decade after its elaboration, the idea of the development of a special political, economic, and social space in Eurasia has special currency among Russian foreign policy makers and politicians.

Alongside with the rational political and economic concepts, some specific ideological constructions and new geopolitical approaches that fall under the rubric of Eurasianism have gradually assumed popularity among government officials and right-wing intellectuals. These ideas were a mixture between traditional geopolitical and philosophical ideas of Slavophiles and Russian geopolitical thinkers of the nineteenth century who associated themselves with the then-popular doctrine of Eurasianism. However, the Eurasianism of the new millennium is based mostly on the idea of confrontation between Russia and the West, and holds that the former Soviet republics are supposed to play a certain buffer role between Russia and the unfriendly West. The most prominent ideas of contemporary Russian Eurasianism have been formulated by Alexander Dugin, one of the leaders of the right-wing Eurasianist and nationalist movement in Russia. They include the following:

- $\quad$ Steering the post-Soviet space in several key areas-political, economic, energy, and strategic — is a key goal for Russian policy and politics

10 It is widely accepted in Russia that the "Color Revolutions" were the result of Western machinations.

11 Sergey Rogov, New Eurasian Strategy for Russia (Moscow: Russian Academy of Sciences, 1998). 
- Developing the "Greater Eurasia" Project (the creation of a buffer between Russia and influential Western and Asian players)

- Making the Eurasian space attractive to former Soviet republics (the idea of a "Eurasian Project" that included the creation of a Eurasian Union was first articulated by Eurasianists in the early 2000s) ${ }^{12}$

- Guaranteeing the territorial integrity and sovereignty of the NIS in exchange for their loyalty to Russia. ${ }^{13}$

Despite the controversial character of some of the thoughts expressed by the Eurasianist ideologists, many of their tenets have been accepted by the Kremlin and have become especially clear in the integration strategy methods utilized by the Russian leadership in early and mid-2000s.

Generally speaking, post-Soviet integration strategies could be divided into three major segments. First, there was a push for the creation of purely political constructions, such as the CIS, as a form of regional cooperation to replace the framework that had been provided by the Soviet Union. The main attribute of such political constructions was their "blurry" character, in which many areas of cooperation are very perfunctory, and a variety of activities and joint projects exist only on paper and never come true. ${ }^{14}$ Most cooperative decisions are made on the basis of ad hoc consensus among particular members who are interested in one project or another. The reason for that was obvious; none of former Soviet republics welcomed the re-emergence of a new Soviet Union. Yet at the same time it was necessary to sustain some instruments for cooperation that could be used when necessary and beneficial for all members. It was true not only for the CIS, but also for the United State of Russia and Belarus, the Collective Security Treaty Organization (CSTO), and other fora of post-Soviet cooperation. ${ }^{15}$ Hence, when we evaluate the efficiency of these organizations in bringing some unity to the post-Soviet space, it is difficult to expect significant progress, because they were not designed to facilitate such goals. And this justifies Russia's endeavor to adopt an additional strategy to be more effective in the area of unification.

The second post-Soviet integration strategy revolved around a variety of decisive measures undertaken by the Russian government in support of its idea of reintegration during the first and second term of Vladimir Putin's presidency. Such measures included either political and financial support for or undermining the acting regimes in the former Soviet Republics (depending on the character of their foreign policy and the willingness to follow a pro-Russian course). This was converted into a "multi-speed and multi-level integration" concept used in relation to the NIS. Russia frequently employed its diplo-

12 See "The Program of the Political Party 'Eurasia',” (Moscow, 2002); available at http://www.evrazia.org/modules.php?name=News\&file=article\&sid=76.

13 Alexander Dugin, Project “Eurasia” (Moscow: Eksmo, 2004), 512.

14 As many as 90 percent of decisions made by CIS structures are not ratified by the member states.

15 That is the reason why, for example, many experts and politicians tend to refer to the creation of the CIS as a form of "civilized divorce." 
matic and especially economic instruments to interfere into the sphere of internal politics of its neighbor states in order to offset U.S. and EU activity.

The results of these measures remained very controversial. The Kremlin's goals often were not achieved, due to a variety of reasons. On the contrary, it has been more than a decade since the post-Soviet republics were proclaimed Russia's top foreign policy priority, yet relations between Russia and many of its neighbors have reached their lowest point since the collapse of Soviet Union. Some indicators of this dismal state of affairs could be found in the series of gas disputes between Russia, Ukraine, and Belarus; the solid drift of some former Soviet republics toward the West and aspirations for NATO and EU membership; the "multi-vector" foreign policy of influential CIS and CSTO members, who seek to pursue their national interests balancing between Russia, the U.S., the EU, and China; and finally, armed conflict between Russia and Georgia. All these may be considered in many respects as signs of Russian political failure in the field of reintegration. The rough results of the integration politics could be described with the "3Ds formula": Disappointment (some regional leaders were disappointed by the perspective of being drawn into the powerful vortex of Russian gravity); Distrust (when it comes to sensitive areas of cooperation between Russia and its neighbors); and Devaluation (for many representatives of the post-Soviet elite, the prospects of reintegration were no longer valuable).

These inconclusive results forced Moscow to rethink its attitude toward the process of post-Soviet integration and switch from empty political constructions and tactics of pressure to a more comprehensive approach, which is more or less based on economic fundamentals and mutual interests as perceived by the CIS members. This third stage of Moscow's reintegration strategy includes prominent measures that should put the integration process on a more pragmatic path, such as the creation of a common market that unifies a significant number (up to 200-250 million) of potential customers and joint industrial and modernization projects.

The major attributes of this newly adopted strategy include several phases:

- Creation of a Customs Union between Russia, Belarus, and Kazakhstan, with the potential of inclusion of other CIS states (started in June 2010)

- The development of a Common Economic Space between the members of the Customs Union, which includes coordination and unification of members' legal, customs, and financial policies, as well as free movement of capital, goods, and labor force (started in January 2012)

- The formation of the Eurasian Economic Union, with certain elements of political unification (planned for 2015).

It should be mentioned, however, that certain gestures toward economic rapprochement have been accompanied by some steps in the sphere of military cooperation between the members of the above-mentioned structures. Those security areas include common air-defense capabilities, joint counter-narcotics and counterterrorist measures, common approaches toward the issues of regional political stability, etc. In other words, the new reintegration strategy is trying to sustain the nexus between the Soviet legacy 
and the new regional realities of the twenty-first century (e.g., common interests, threats, and visions of regional development). The Russian idea of the creation of common economic structures goes hand in hand with its interest to strengthen military and security ties with members of newly created organizations. It means that the modern form of regionalism based on shared economic interests has a strong dimension of building a political alliance inherited from the Soviet past.

However, the big question that arises from the above-mentioned strategy is to what extent the idea of the EU's Eastern Partnership could co-exist with Russia's reintegration strategies? Russia made no secret of its suspicion of any modes of political cooperation between the former Soviet Republics and the West, but could this be seen through the prism of new geopolitical competition?

The EU and Russia are the most important actors in the shared vicinity, both exercising structural and normative power to shape their neighboring environment and both seeking to coordinate the external challenges emanating from the region. Whereas the EU has launched a concrete strategy for its immediate eastern neighbors (most prominently, through the EaP), Russia has also striven to maintain an upper hand by envisaging a range of hard- and soft-power instruments and institutional frameworks to exploit its structural power in the post-Soviet space. Both players endeavor to mold the neighboring countries according to its own pattern. The most recent example has been the effort to entice the six post-Soviet states from Eastern Europe into either Association Agreements or the soon-to-be Customs Union. There is a lack of compatibility between these two forms of integration, which lies both in the mechanisms for setting the external tariff and the competition between different standards and regulations. This places some of the countries from the common proximity in a conundrum over whether to choose deeper integration into the EU or a closer relationship with the future Eurasian Union. Nonetheless, looking at both processes of EU and Russian activities in the post-Soviet space, we may assert that they could be mutually beneficial for the countries involved. This implies a genuine, constructive approach rather than a competitive one, which is the unequivocal message both Russia and the EU ought to convey to each other in order to reach their goals. Such an approach ought to be simultaneously realistic and complementary to the greatest possible extent. The essence of this message-cooperation based on mutual benefit—should also undergird the negotiations for a new basic agreement on a Strategic Partnership to update and replace the existing Partnership and Cooperation Agreement. Having in mind the current backdrop-which is marked by emerging security challenges, new international developments, and the persistent effects of the global economic crisis - we uphold the view that both the EU and Russia need to undergo a paradigm shift from geopolitical competition to consolidated partnership. A strong partnership under which the two important players could genuinely cooperate would maximize the strengths of necessarily similar approaches, bring about regional stability, and spare the neighboring states from having to negotiate a difficult balancing act between East and West. 
THE QUARTERLY JOURNAL

\section{References}

Smith, Michael, and Mark Weber. "Political Dialogue and Security in the European Neighbourhood: The Virtues and Limits of 'New Partnership Perspectives'," European Foreign Affairs Review 13, no. 1 (2008): 73-95.

Lungescu, Oana. “EU Reaches out Toward Troubled East,” BBC News, 2009.

Füle, Štefan. “Ambitions of EU and East Partners for the Vilnius Summit," Press Releases Rapid, 2013.

European Commission. Eastern Partnership: A Roadmap to the Autumn 2013 Summit. 2012.

Rogov, Sergey. New Eurasian Strategy for Russia. Moscow: Russian Academy of Sciences, 1998.

The Program of the Political Party 'Eurasia'. Moscow, 2002.

Dugin, Alexander. Project “Eurasia”. Moscow: Eksmo, 2004. 